\title{
Identification of Iron rich rice genotypes in Bangladesh using chemical analysis
}

\author{
G. S. Jahan*, L. Hassan, S. N. Begum ${ }^{1}$ and S. N. Islam \\ Department of Genetics and Plant Breeding, Bangladesh agricultural University, Mymensingh-2202, Bangladesh and \\ ${ }^{1}$ Plant Breeding Division, Bangladesh Institute of Nuclear Agriculture, Mymensingh-2202, Bangladesh, *E-mail: \\ gsjahan57@yahoo.com
}

\begin{abstract}
Rice (Oryza sativa L.) is the most important food crop of the developing world and the staple food of more than half the global population. An experiment was carried out to identify the iron rich rice genotypes. Total fifty two rice genotypes were used for this purpose. Iron (Fe) content of rice grain samples was determined by using Atomic Absorption Spectrophotometer (AAS). In this process the samples were digested by the application of di-acid mixture which includes nitric acid $\left(\mathrm{HNO}_{3}\right)$ : and perchloric acid $\left(\mathrm{HClO}_{4}\right)$ in 2:1 ratio. Iron content was estimated in the aliquot of seed extract by using Atomic Absorption Spectrophotometer (AAS) at $248.33 \mathrm{~nm}$. Iron concentration ranged from $1.32 \mathrm{ppm}$ (Jota Balam) to 100.45 ppm (Lal Gotal). Among the 52 genotypes local landraces had showed the highest Fe content. In this experiment, ANOVA table revealed that significant variation was found among the genotypes for the iron concentration. This suggested that there were inherent genetic differences among the genotypes. Thus, local landraces can be a good source for biofortification of popular rice cultivars using different breeding methods.
\end{abstract}

Keywords: Iron, Rice genotypes, Atomic Absorption Spectrophotometer (AAS), Biofortification

\section{Introduction}

Rice is one of the most important cereal crops in Bangladesh and it is the main staple food for the people. It provides nearly $48 \%$ of rural employment, about two-thirds of total calorie supply, and about one-half of the total protein intakes of an average person in the country. Rice sector contributes one-half of the agricultural GDP and one-sixth of the national income in Bangladesh. About $75 \%$ of the total cropped area and more than $80 \%$ of the total irrigated area is planted to rice. Almost all the 13 million farm families grow rice. Among the large population of this country a large portion suffered in malnutrition and one of the important ways to mitigate this problem by growing nutritional quality improved rice cultivars. In Bangladesh, 11528.51 thousand hectares of land produces 33540.32 thousand metric tons of rice (BBS, 2012).

In the last two decades, new research findings generated by the nutritionists have brought to light the importance of micronutrients, vitamins and proteins in maintaining good health, adequate growth and even acceptable levels of cognitive ability apart from the problem of protein energy malnutrition. (Nagesh et al., 2012).

Iron deficiency is the most common nutritional disorder in the globe affecting between 2 to 5 billion people. In Bangladesh $49 \%$ of pregnant woman and 53\% of preschool children are anemic due to iron deficiency (Hossain and Hussain, 2004). The severe form of iron deficiency affects about 3.5 billion worldwide (Kracht, 1999; Ahman et al., 2000). Overall, 39\% of preschool children and 52\% of pregnant woman are anemic; more than $90 \%$ of them are living in the developing countries. In infant and young children, it impairs immunity, reduces the physical growth and cognitive development; at school age it affects school performance and reduces activity levels; at adulthood, it reduces work capacity and decrease resistance to fatigue. In pregnant women, iron deficiency anemia is associated with an increased risk of pre-mature delivery, retarded growth of the fetus, low birth weight and increased risk that the new born baby die soon after birth. Anemia is the main cause of death during childbirth (Chrispeel and Sadava, 1994). 
This study will help in identifying the iron rich rice genotypes among the existing Bangladeshi genotypes. This study will also help in the developing nutritionally improved rice cultivar, training of young scientists in developed laboratories to provide a pool of human resources competent in molecular breeding techniques along with the development of rice varieties with enhanced nutritional quality.

\section{Materials and Methods}

\section{Experimental site}

This experiment was conducted at the experimental laboratory of Department of Agricultural Chemistry, Bangladesh Agricultural University and Soil Science Division of Bangladesh Institute of Nuclear Agriculture (BINA), Mymensingh, during June 2012 to January 2013.

\section{Experimental materials}

A total of fifty two (52) rice genotypes, consisting of forty (40) landraces representing southern and northern part of Bangladesh, five (5) high yielding varieties (HYV), three (3) mega varieties and four (4) advanced lines were collected to carry out the objectives of this research work. List of the rice genotypes are presented in Table 2.

\section{Processing of seeds}

Processing of seeds of fifty two rice genotypes for chemical analysis was done by dehusking and grinding. Before analyzing the rice samples for iron estimation, the seeds of all the 52 accessions were subjected to dehusking and grinding. The collected rice seeds were oven dried at $55^{\circ} \mathrm{C}$ temperatures for 48 hours to facilitate the dehusking process. The oven dried seeds were then placed in winnower and rubbed across it for the dehusking purpose. The dehusked seeds were then grinded to make it powder with the help of a mechanical grinder. The rice grain powder of each genotypes was then stored in a polythene bag. From there one gram $(1 \mathrm{~g})$ of the rice grain powder for each genotypes was weighed separately for the further use.

\section{Determination of iron content from the rice grain sample}

Iron (Fe) content of rice grain samples was determined by using Atomic Absorption Spectrophotometer (AAS) as stated by Lindsay and Novell (1978). In this process the samples were digested by the application of di-acid mixture (Bhatia and Khetarpaul, 2012; Shaibur et al., 2010) which includes nitric acid $\left(\mathrm{HNO}_{3}\right)$ : and perchloric acid $\left(\mathrm{HClO}_{4}\right)$ in 2:1 ratio. The detailed procedure of this process described below.

\section{Procedure of Digestion of rice grain for Iron (Fe) estimation}

From the each genotypes one gram (1g) amount of rice grain powder was taken in $150 \mathrm{ml}$ conical flask and $10 \mathrm{ml}$ of di-acid mixture $\left(\mathrm{HNO}_{3}: \mathrm{HClO}_{4}=2: 1\right)$ added to it. It was kept overnight at room temperature (2.00 PM to $11.00 \mathrm{AM}$ ). Then the conical flask was placed on sand bath at temperature $180 \sim 200^{\circ} \mathrm{C}$ for 30 40 minutes. After a few minutes brown fume was evolved. This indicated the starting of digestion process. Finally white fume was seen by clearing the solution. At the bottom of the conical flask about 2-3 $\mathrm{ml}$ solution was noticed. After that heating was stopped and the digested sample was cooled for 20 minutes. Then about 20 30 ml distilled water was added to each conical flask. Then this solution was filtered into a $50 \mathrm{ml}$ volumetric flask and the volume was made up to the mark $(50 \mathrm{ml})$ by adding distilled water. The $50 \mathrm{ml}$ solution was then transferred into a plastic bottle for each genotype for the further use in future. The plastic bottle was stored at a room temperature. Total procedure is outlined as a flow diagram as follows: 
Flow diagram for the estimation of Iron (Fe) content from rice grain

$1 \mathrm{~g}$ rice grain powder in $150 \mathrm{ml}$ conical flask

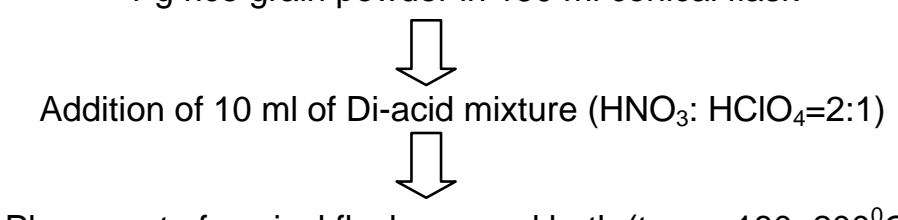

Placement of conical flask on sand bath (temp. $180 \sim 200^{\circ} \mathrm{C}$ )<smiles>C1CCC1</smiles>

Brown fume evolves (within few minutes)<smiles>C1CCCC1</smiles>

White fume evolves (after 30 40 minutes)<smiles>C1CCC1</smiles>

Cooling the sample for 20 minutes<smiles>C1CCCC1</smiles>

Addition of $20 \sim 30 \mathrm{ml}$ distilled water<smiles>C1CCCC1</smiles>

Filtration of the solution in $50 \mathrm{ml}$ volumetric flask<smiles>C1CCCC1</smiles>

Making the Volume up to the mark $(50 \mathrm{ml})$<smiles>C1CC2CCCC2C1</smiles>

Transferring the sample in plastic bottle \& store at room temperature

\section{Iron (Fe) content determination by AAS}

It is based on the principle that atoms of iron (Fe) which is normally remain in ground state, under flame condition absorb energy when subjected to radiation is proportional to the specific wavelength. The absorption of radiation is proportional to the concentration of iron. Iron content was estimated in the aliquot of seed extract by using Atomic Absorption Spectrophotometer (AAS) at $248.33 \mathrm{~nm}$.

\section{Results and Discussion}

\section{Fe concentration analysis}

Fe concentration in all the genotypes was analyzed using Atomic Absorption Spectrophotometer at Soil Science Division, Bangladesh Institute of Nuclear Agriclture (BINA), Mymensingh. Seeds from all varieties were dehusked gently. Concentration was expressed in parts per million (ppm). Calibration graph was constructed (Fig. 1) from iron standards containing the concentrations given in the Table 1.

Table 1. Data on Iron concentration \& absorbance for calibration graph

\begin{tabular}{|c|c|c|}
\hline Sl. No. & Fe Conc.(ppm) & Absorbance \\
\hline 1 & 0 & 0.00 \\
\hline 2 & 0.5 & 0.06 \\
\hline 3 & 1.0 & 0.12 \\
\hline 4 & 2.0 & 0.22 \\
\hline 5 & 3.0 & 0.31 \\
\hline 6 & 4.0 & 0.39 \\
\hline 7 & 5.0 & 0.45 \\
\hline
\end{tabular}




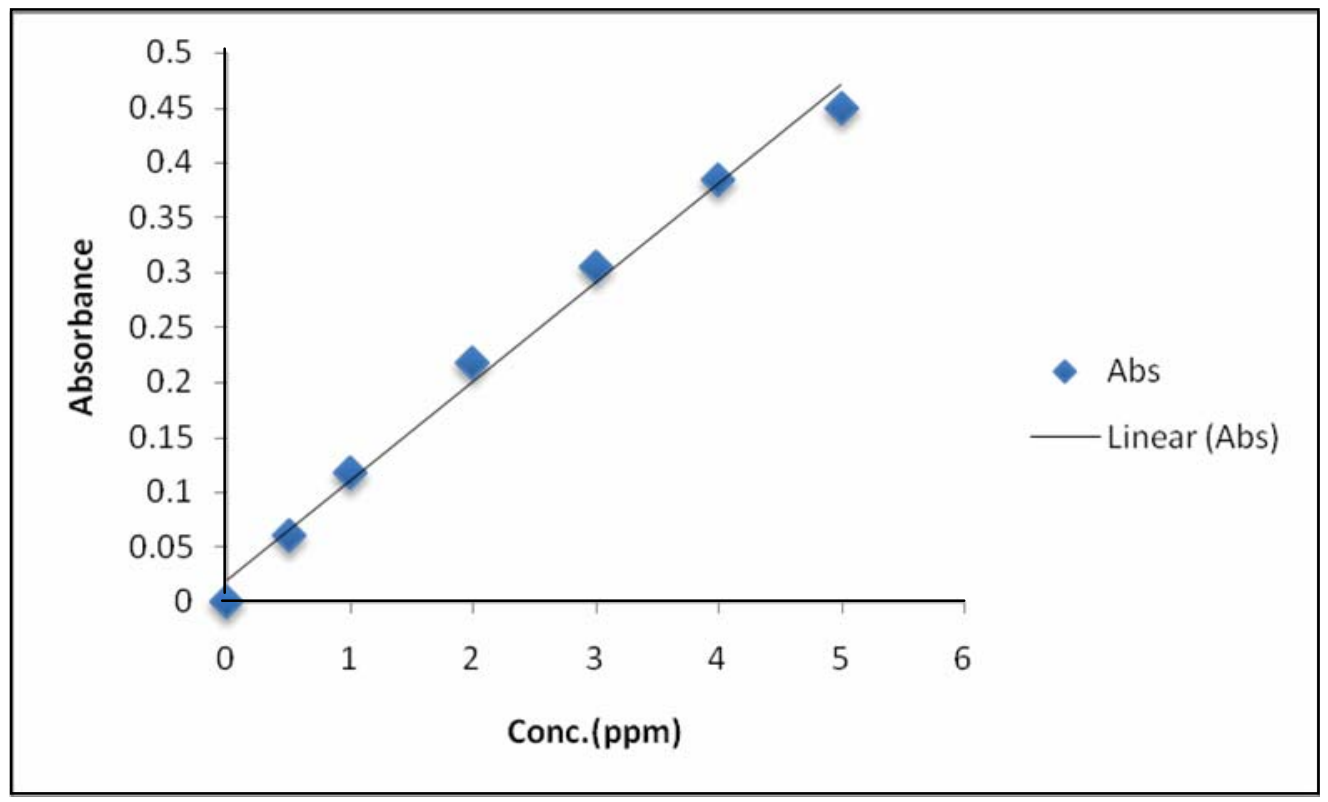

Fig. 1. Calibration graph by plotting iron concentration \& absorbance

A minimum of two replications from each of the cultivars and local genotypes were analyzed for Fe. The di-acid method of digestion was followed. The variation in replications for each sample did not exceed \pm $2 \mathrm{ppm}$ for Fe. The mean of the two replicates was presented in results (Table 2).

Table 2. Mean performance of 52 rice genotypes based on Iron (Fe) Concentration

\begin{tabular}{|c|c|c|}
\hline SI. No. & Name of the variety & Iron Concentration (mean) (ppm) \\
\hline 1 & Dudh Kalam & 16.69 \\
\hline 2 & Enghi & 55.91 \\
\hline 3 & Kajol Shail & 11.98 \\
\hline 4 & Jamai Naru & 14.94 \\
\hline 5 & Hari & 12.97 \\
\hline 6 & Dakh Shail & 37.15 \\
\hline 7 & Moina Moti & 73.61 \\
\hline 8 & Patnai & 5.57 \\
\hline 9 & Kute Patnai & 62.29 \\
\hline 10 & Mohini Shalot & 23.75 \\
\hline 11 & Moghai Balam & 16.58 \\
\hline 12 & Khak Shail & 88.52 \\
\hline 13 & Holde Gotal & 11.80 \\
\hline 14 & Jota Balam & 1.32 \\
\hline 15 & Durga Bhog & 18.15 \\
\hline 16 & Khainol & 11.29 \\
\hline 17 & Ghunshi & 12.56 \\
\hline 18 & Chinikani & 13.44 \\
\hline 19 & Hamai & 92.21 \\
\hline 20 & Mura Bajal & 9.79 \\
\hline 21 & Lal Gotal & 100.45 \\
\hline 22 & Sylhet Balam & 20.09 \\
\hline 23 & Mota Aman & 15.64 \\
\hline 24 & Ghochi & 11.49 \\
\hline 25 & Tal Mugur & 3.45 \\
\hline 26 & Tor Balam & 7.94 \\
\hline
\end{tabular}


Table 2 Contd.

\begin{tabular}{|c|c|c|}
\hline SI. No. & Name of the variety & Iron Concentration (mean) (ppm) \\
\hline 27 & Fulkainja & 49.60 \\
\hline 28 & Piarjat & 9.42 \\
\hline 29 & Koicha Binni & 8.25 \\
\hline 30 & Lal Biroi & 5.11 \\
\hline 31 & Kakua Binni & 60.72 \\
\hline 32 & Nona Bokhra & 14.37 \\
\hline 33 & Sada Binni & 30.25 \\
\hline 34 & Kalo Binni & 18.85 \\
\hline 35 & Jongli Boro & 6.88 \\
\hline 36 & Kashrail & 9.76 \\
\hline 37 & Ledra Binni & 11.57 \\
\hline 38 & Roti Shail & 13.85 \\
\hline 39 & Lal Binni & 18.83 \\
\hline 40 & Kali Boro & 16.13 \\
\hline 41 & BR 11 & 63.53 \\
\hline 42 & BRRI dhan 28 & 35.81 \\
\hline 43 & BRRI dhan 29 & 69.12 \\
\hline 44 & BRRI dhan 52 & 26.82 \\
\hline 45 & BRRI dhan 55 & 14.10 \\
\hline 46 & BRRI dhan 57 & 66.52 \\
\hline 47 & BINA dhan-7 & 9.02 \\
\hline 48 & BINA dhan-8 & 21.38 \\
\hline 49 & GPB-F-1 & 17.71 \\
\hline 50 & GPB-F-2 & 31.47 \\
\hline 51 & Samba Mashuri & 20.13 \\
\hline \multirow[t]{6}{*}{52} & Cheheran & 11.07 \\
\hline & $\mathrm{CV} \%$ & 2.29 \\
\hline & Minimum & 1.32 \\
\hline & Maximum & 100.45 \\
\hline & Mean & 27.11 \\
\hline & LSD at $5 \%$ & 1.73 \\
\hline
\end{tabular}

Analysis of variance (ANOVA) was constructed to determine the variations among the concerned genotypes (Table 3).

Table 3. Analysis of variance for screening of iron rich rice genotypes

\begin{tabular}{|l|c|c|c|c|}
\hline Source of variation & Degrees of freedom & Sum of Squares & Mean square & F-value \\
\hline Between & 51 & 64558.942 & 1265.862 & $3014.390^{\star \star}$ \\
\hline Within & 52 & 21.837 & 0.420 & \\
\hline Total & 103 & 64580.778 & & \\
\hline
\end{tabular}

** indicates significant at 0.01 probability

A wide range of variation was observed among fifty two rice (Oryza sativa L.) genotypes for iron concentration. The perusal of data revealed that variance due to genotypes was highly significant for the iron concentration (Table 2). This suggested that there were inherent genetic differences among the genotypes. Significant genetic variation for iron content exhibited by the genotypes indicated this character might be effective for further crop improvement. Total 52 accessions of rice genotypes were analyzed for iron (Fe) concentration. Iron concentration ranged from $1.32 \mathrm{ppm}$ to $100.45 \mathrm{ppm}$. Among the 52 genotypes local landraces i.e. Lal Gotal, Hamai, Khak Shail, Moina Moti, Kute Patnai, Kakua Binni, Enghi and commercially cultivated varieties i.e. BRRI dhan 29, BRRI dhan 57, BR 11 had showed the highest Fe content. The iron content of local landraces is higher than the others which is supported by the findings that were earlier reported by llango and Sarla (2010), Banerjee et al., (2010) and Anuradha et al., (2012). Banerjee et al., (2010) screened 46 rice lines including cultivated and wild accessions and 
showed that wild rice accessions have higher grain Fe concentration. Anuradha et al. (2012) reported that they analyzed brown rice of 126 accessions of rice genotypes for Fe concentration. Iron concentration ranged from $6.2 \mathrm{ppm}$ to $71.6 \mathrm{ppm}$ and the local accessions had the highest Fe. In this study few genotypes (local landraces) had showed higher iron concentration than the previously reported. Thus, local landraces are a good source for biofortification of popular rice cultivars using different breeding methods.

\section{Conclusion}

Screening of germplasm for Fe content is the initial step of biofortification. In this study 52 genotypes were screened to identify iron rich rice in Bangladesh. The local landrace, Lal Gotal had the highest (100.45 ppm) iron concentration where as Jota Balam had the lowest amount of iron concentration (1.32 ppm). Among the commercial cultivated varieties; BR 11, BRRI dhan 29 and BRRI dhan 57 have the considerably higher amount of iron content, so it can be proposed to eat these rice varieties to cope with iron deficiencies. Furthermore, among the screened materials, the genotypes having higher iron content can be used as a breeding material for biofortification process in future.

\section{Acknowledgements}

This project has been funded by the Sponsored Public Goods Research (SPGR); PIU-BARC, NATP: Phase 1, Bangladesh Agricultural Research Council (BARC), Project ID: SPGR-400 entitled "Rice Biotechnology: Application of microsatellite markers for screening and identification of iron rich rice genotypes". The principal author is thankful to Dr. Kartik Chandra Saha, Department of Agricultural Chemistry, Bangladesh Agricultural University, Mymensingh for his supervision during the chemical analysis. We would also like to extend our thanks to Dr. Md. Monowar Karim Khan and Md. Tarikul Alam; Soil Science Division, Bangladesh Institute of Nuclear Agriculture (BINA) for helping in the determination of iron content using Atomic Absorption Spectrophotometer (AAS).

\section{References}

Ahman E., Allen, H., Beaton, G., Benoist, B., Flores B., Gilespe, S., Robeneck, S. and Viteri, F., 2000. Nutrition through the life cycle- $4^{\text {th }}$ Report on the World Nutrition Situation: ACC/SCN in collaboration with IFPRI, Geneva, Switzerland, p. 23-27.

Anuradha K., Agarwal, S., Batchu, A. K., Babu, A. P., Swamy, B.P. M., Longvah, T. and Sarla, N. 2012. Evaluating rice germplasm for iron and zinc concentration in brown rice and seed dimensions. Journal of Phytology, 4(1):19-25.

Banerjee S., Sharma, D.J., Verulkar, S.B. and Chandel, G. 2010. Use of in silico and semiquantitative RT-PCR approaches to develop nutrient rich rice (Oryza sativa L.). Ind. J. Biotechnol 9(2): 203-212.

BBS, 2012. The Year Book of Agricultural Statistics of Bangladesh. Bangladesh Bureau of statistics, Stat. Div. Ministry. Plan., Govt. Peoples Rep. Bangladesh. Dhaka, p.123-127.

Bhatia, A. and Khetarpau,I N. 2012. 'Doli ki roti'- An indigenously fermented Indian bread: Cumulative effect of germination and fermentation on bioavailability of minerals. Indian Journal of tradiTtional Knowledge.Vol.11(1),p.109-113.

Chrispeels, M.J. and Sadava, D.E. 1994. Plants, Genes and Agriculture, Jones and Bartlett publishers, the United States. pp. 100101.

Hossain, M., Husain, M. and Datta, S.K. 2004. Rice Biotechnology: Opportunity, Perceived Risks and Potential Benefits to Bangladesh. Centre for Policy Dialogue, CPD Occasional Paper Series 37.

llango S. and Sarla N. 2010. Microsatellite marker polymorphism in rice varieties rich in iron and zinc endosperm. Asian j. Exp. Biol. Sci. Vol. 1(4):751- 757.

Kracht U. 1999. In: Kracht, U. and Shultz, M. (eds.), Food Security and Nutrition-The Global Challenge, Palgrave Macmillan, New York, USA. p.68-69.

Lindsay W.L. and Novell, W.A. 1978. Soil Science Society of America Journal.42: 421-428.

Nagesh V., Ravindrababu, G., Usharani and Reddy, T.D. 2012. Grain iron and zinc association studies in rice (Oryza sativa L.) F1progenies. Archives of Applied Science Research, 4 (1):696-702.

Shaibur M.R., Shamim, A.H.M., Huq, S.M.I. and Kawai, S. 2010. Comparison of digesting capacity of nitric acid and nitric acidperchloric acid mixture and the effect of lanthanum chloride on potassium measurement. Nature and Science;8(5):157162. 